\title{
Vitamin D deficiency in women with uterine fibroids versus Vitamin D deficiency in the general population
}

\author{
Leigh D Rosen, Suzanne K Fenske, Heather M Isola and Charles J Ascher-Walsh* \\ Department of Obstetrics, Gynecology and Reproductive Science, Mount Sinai Hospital, New York, USA
}

\begin{abstract}
Introduction: To estimate the prevalence of vitamin D deficiency in women with leiomyomas compared to that of the general population.

Materials/Methods: Cross-sectional study from a single high volume Surgeon's office Vitamin D levels in women with MRI or ultrasound documented uterine fibroids who came to one surgeon's office for follow up or initial visit June 2012 to September 2012. The data was analyzed in 2017. The women were compared to the vitamin D status of the U.S. population according to the National Health and Nutrition Examination Surveys.
\end{abstract}

Results: The prevalence of vitamin D deficiency in women with uterine fibroids was $85 \%$ compared to the prevalence of vitamin D deficiency in the general population of the United States which was $8 \%$.

Conclusion: Women with uterine fibroids are more likely than the general population to be deficient in vitamin $\mathrm{D}$ indicating that vitamin $\mathrm{D}$ deficiency may serve as a risk factor for fibroid growth and development.

\section{Introduction}

Uterine fibroids, or leiomyomas are the most common benign tumors of the female reproductive tract, affecting up to $80 \%$ of American women [1]. with only $25 \%$ of women who are symptomatic. Symptoms do not always correlate with the size, number, or location of the fibroids $[1,2]$.

For a long time, fibroid development and growth has been associated with hormones, namely estrogen and progesterone $[3,4]$. Unfortunately, treatments that interfere with estrogen have proven to be more effective in animal models than in humans [1].

In 2009, Blauer, Rovio, Ylikomi, and Heinonen, looked at vitamin D and its effect on myometrial and fibroid cell proliferation in vitro. They found that when treated with a physiologic concentration of vitamin $\mathrm{D}$, both normal myometrial and fibroid cell growth was significantly suppressed [5]. Taking this vitamin D theory steps further, Halder, Sharan, and Al-Hendy found that treatment with 1.25-dihydroyvitamin D3 significantly decreased uterine fibroid tumor volumes [6].

While there is a plethora of research looking at the therapeutic mechanisms of vitamin $\mathrm{D}$ there have been no clinical studies evaluating the frequency of vitamin D deficiency in women with uterine fibroids compared to the general population. The overall goal of this crosssectional analysis was to estimate the prevalence of vitamin $\mathrm{D}$ deficiency in women with uterine fibroids and to compare them to the general population.

\section{Materials/Methods}

This is a cross sectional analysis. Eligible patients presented to the office, as either follow-up or initial visits with MRI or ultrasound confirmed fibroids from June 2012 to September 2012, and analyzed in 2017. During the visit, patients were informed of the new evidence that vitamin $\mathrm{D}$ might play a role in uterine fibroid regulation and were given the option of having their $25(\mathrm{OH})$ vitamin D levels checked. Charts (electronic) were then extracted and reviewed.

Demographic data was collected including age, race, past medical history, and prior medical or surgical treatments for uterine fibroids. Additionally, in-office sonogram results were collected noting overall uterine size and largest fibroid size. Inclusion criteria were all women with documented uterine fibroids. Women were excluded with renal disease and or parathyroid disease.

Optimal level of vitamin D has been suggested to be over $30 \mathrm{ng} /$ $\mathrm{mL}$ as such a level is associated with suppression of PTH (parathyroid hormone), decreased fracture rates, and overall improved health outcomes [7]. While the definition of Vitamin D deficiency tends to vary, we decided to utilize the 2011 Endocrine Society definition of vitamin D deficiency $(<20 \mathrm{ng} / \mathrm{mL})$, and vitamin D insufficiency (21$29 \mathrm{ng} / \mathrm{mL}$ ) [8]. To assess the prevalence of vitamin D deficiency in the United States, we utilized data from the National Health and Nutrition Examination Survey (NHANES) from 2001-2006 [9]. According to NHANES, vitamin D deficiency is defined as $25(\mathrm{OH}) \mathrm{D}$ value less than $30 \mathrm{nmol} / \mathrm{L}$ (equivalent to $12 \mathrm{ng} / \mathrm{mL}$ ).

Statistical Package for the Social Sciences was used for comparisons. $P$ values of less than 0.05 were considered statistically significant. This study was approved by the Mount Sinai Hospital Institutional Review Board.

${ }^{*}$ Correspondence to: Charles Ascher-Walsh, MD, 1176 5th Avenue, 9th Floor, New York, NY 10029, USA, Tel: (212) 241-7809; Fax: (212) 241-4787; E-mail: charles.ascher-walsh@mssm.edu

Key words: uterine fibroids, vitamin D, deficiency, growth, treatment

Received: November 05, 2018; Accepted: November 14, 2018; Published: November 16, 2018 


\section{Results}

During the study period, we identified 52 patients who met the inclusion criteria. Out of 52 patients, $86.5 \%$ of the patients had vitamin $\mathrm{D}$ levels below $30 \mathrm{nmol} / \mathrm{L}$ (vitamin D deficient according to NHANES). According to the definitions established by the 2011 Endocrine Society, $50 \%$ were deficient and $36.5 \%$ were insufficient. The mean vitamin D level was $23.3 \mathrm{ng} / \mathrm{mL}$.

According to the National Health and Nutrition Examination Surveys that looked at vitamin D levels in the United States population from 2001 to $2006,8 \%$ of the general population was vitamin D deficient $(25(\mathrm{OH}) \mathrm{D}$ levels below $30 \mathrm{nmol} / \mathrm{L})$. A study done in 2008 found approximately $41 \%$ of men and $53 \%$ of women in the United States have vitamin D levels below $28 \mathrm{ng} / \mathrm{mL}$ [7]. In our study population, $85 \%$ percentage of people had vitamin D levels below $28 \mathrm{ng} / \mathrm{mL}$. A recent study by Forrest and Stuhldreher, which defines vitamin D deficiency as less than or equal to $20 \mathrm{ng} / \mathrm{mL}$, found the overall prevalence rate of vitamin D deficiency in the American population to be $41.6 \%$, [10]. Additionally, Zhao, Ford, Tsai, Li, and Croft studied vitamin D deficiency and inadequacy, which they defined as less than $12 \mathrm{ng} / \mathrm{mL}$ and less than $20 \mathrm{ng} / \mathrm{mL}$ respectively, among women in the United States and found the mean $25(\mathrm{OH}) \mathrm{D}$ concentration to be $24.1 \mathrm{ng} / \mathrm{mL}$ with a prevalence of vitamin $\mathrm{D}$ deficiency of $11.1 \%$ and inadequacy was $25.7 \%$. They also found the mean vitamin $\mathrm{D}$ concentration to be lowest among non-Hispanic black women and the prevalence of both vitamin $\mathrm{D}$ inadequacy and deficiency to be highest among non-Hispanic black women [11].

When compared to the prevalence of vitamin D deficiency in the general population, women with uterine fibroids have an increased prevalence of vitamin $\mathrm{D}$ deficiency across the board. They also have a mean $25(\mathrm{OH})$ vitamin $\mathrm{D}$ of $23.3 \mathrm{ng} / \mathrm{ml}$, supporting the notion that low levels of vitamin D might serve as a potential risk factor for fibroid development and growth.

\section{Discussion}

Results from our study indicate that approximately $85 \%$ of women with documented uterine fibroids had $25(\mathrm{OH}) \mathrm{D}$ levels below the lower cutoff for normal range $(<30 \mathrm{ng} / \mathrm{ml})$ and that women with fibroids have an increased prevalence of vitamin D deficiency when compared to the general population.

Therehasbeen ample researchinvestigating themechanismsbywhich vitamin D acts as a regulator of various diseases. The aforementioned Eker rat study utilized western blot and immunohistochemical analysis to uncover the cellular changes that vitamin D causes in uterine fibroids. They found that vitamin D reduced the level of PCNA (proliferating cell nuclear antigen), along with cell cycle regulatory proteins like CDK1, 2, and 4. PCNA aids in DNA synthesis and replication while CKD1, 2 and 4 are proteins that aid in cell cycle progression [6]. Reducing expression of such proteins is one explanation for vitamin D's antiproliferative effects on uterine fibroids.

The study also demonstrated that the addition of vitamin D reduced the levels of anti-apoptotic proteins, BCL2 and BCL2L1, and slightly increased the pro-apoptotic BAD protein and caspase 3 in uterine fibroids [6]. It is not surprising that an overall increase in proapoptotic proteins after treatment with vitamin D might also explain the inhibitory effects of vitamin $\mathrm{D}$ on cell growth.

Research has demonstrated that uterine leiomyomas have a tendency to over express cyclin D1, whose activity is required for cell cycle progression from G1 to $S$ phase, along with an overexpression of proto-oncogene MYC that promotes cell proliferation and has been linked to various cancers. The Eker rat study noted that expression of both cyclin D1 and proto oncogene MYC were significantly reduced in the vitamin $\mathrm{D}$ treated uterine leiomyomas compared to the control group [6]. It is clear from the Eker rat study that vitamin D's potentially therapeutic effect on shrinking uterine fibroids might stem from its antiproliferative and pro apoptotic mechanisms.

The hormonal effects of estrogen and progesterone on uterine leiomyomas have long been established and are evidenced clinically by their shrinkage after menopause. The Eker rat study demonstrated that vitamin D treated fibroids exhibited reduced expression of Estrogen Receptor 1 (ESR1), Progesterone Receptor A (PGR-A), and Progesterone Receptor B (PGR-B) [6]. It is therefore possible that through this mechanism, vitamin $D$ results in shrinkage of uterine fibroids.

Research has supported the notion that uterine fibroids contain increased mRNA and protein expression of catechol-Omethyltransferase, an enzyme involved in the biological estrogen pathway [12]. A study in January of 2011 found that not only did vitamin $\mathrm{D}$ inhibit the growth of human uterine leiomyoma cells by $47+/-.03 \%$ at $1 \mu \mathrm{M}$ and by $38+/-.02 \%$ at $.01 \mu \mathrm{M}$ compared to controls but also that it was through the mechanism of decreasing catecholO-methyltransferase. While this study demonstrated that similar to previous studies; addition of vitamin D reduced expression of kinases, BCL-2, BCL-w, CDK1 and PCAN, by noting a decrease in catecholO-methyltransferase with addition of vitamin $D$, suggests that the estrogen pathway might be the mechanism by which vitamin $D$ inhibits fibroid growth $[13,14]$.

Studies have demonstrated that uterine fibroids are characterized as having a large extracellular matrix composed of both collagen and fibronectin. Research has revealed that this is due to over-expression of collagen type 1 and fibronectin in uterine fibroids. When treated with vitamin $\mathrm{D}$, however, western blot analysis demonstrated a 2 -fold decrease in fibronectin and a 4 -fold decrease in collagen type 1 expression in uterine fibroids, suggesting yet another mechanism by which vitamin D might serve to inhibit uterine fibroid growth. [15]

A recent study exposed mesenchymal multipotential cells to active vitamin $\mathrm{D}$ and found that the addition of vitamin $\mathrm{D}$ not only decreased expression of pro fibrotic factors like tgfbl and plasminogen activator inhibiter along with expression of collagen I, III but also increased expression of antifibrotic factors like BMP7 a tgfb1 antagonist, MMP8 a collagen breakdown inducer and follistatin, an inhibitor of the profribtoc factor myostatin, further exemplifying the antiproliferative effects of vitamin D [14].

Another in vitro study looking at vitamin $\mathrm{D}$ and its antiproliferative effects found that, similar to that which was found in the Eker rat study, the addition of vitamin $\mathrm{D}$ leads to a reduction of cells in the $S$ phase (DNA synthesis phase). Their study supported the notion that it is vitamin D's effect on cyclin dependent kinase inhibitors; p21 and p27 that inhibits cell growth [5].

As tgf $\beta$ has been defined as one of the key players in the growth factor pathway of uterine fibroids, Halder, Goodwin, and Al-Hendy's study examined the effects of vitamin $\mathrm{D}$ on $\operatorname{tgf} \beta$ specifically in uterine cells. In their study, human uterine leiomyoma cells were treated with tgf $\beta 3$ with or without vitamin $D$. It was found that the pro fibrotic and proliferative effects of $\operatorname{tgf} \beta$ on leiomyomas; induction of fibronectin and collagen type 1 progression, induction of plasminogen 
activator inhibitor 1 protein expression, phoshporylation and nuclear translocation of $\operatorname{tgf} \beta$ cell signaling mediators SMAD2 and SMAD 3 were all significantly reduced when treated with vitamin D [15].

\section{Conclusion}

The vast array of mechanisms by which vitamin $\mathrm{D}$ regulates cell growth combined with the evidence that women with uterine fibroids have a higher prevalence of hypovitaminosis D than the general population emphasizes the need to evaluate the use of vitamin $\mathrm{D}$ as a non-invasive and potentially therapeutic option for fibroids. Currently, hysterectomy remains the main option for treatment of uterine fibroids. More than 600,000 hysterectomies are performed each year in the US, with fibroids being the most common indication for the procedure [6]. While surgical treatment for uterine fibroids is the mainstay, the associated risks of morbidity, mortality, and infertility cannot be overlooked and the need for a safe effective nonsurgical therapeutic strategy is critical.

While hypovitaminosis D might serve as a risk factor for uterine fibroids, research needs to be done to assess the use of vitamin D as a non-invasive and successful therapy to prevent leiomyoma growth in women.

\section{Declarations}

Leigh Rosen MD, Suzanne Fenske MD, Heather Isola RPA-C, Charles Ascher-Walsh MD attest that they have met all authorship criteria.

We would like to acknowledge Kristen Coohill for her editorial and submission assistance.

The authors report no external funding source for this study.

The authors declare they have no competing interests.

\section{References}

1. Laughlin Sk, Sterwart EA (2011) Uterine leiomyomas: individualizing the approach to a heterogeneous condition. Obstet Gynecol 117: 396-403. [Crossref]
2. Spies JB, Bradley LD, Guido R, Maxwell GL, Levine BA, et al. (2010) Outcomes from leiomyoma therapies: comparison with normal controls. Obstet Gynecol 116: 641-652. [Crossref]

3. Walker CL, Stewart EA (2005) Uterine fibroids: the elephant in the room. Science 308: 1589-1592. [Crossref]

4. Nesby-O'Dell S, Scanlon KS, Cogswell ME, Gillespie C, Hollis BW, Looker AC, et al (2002) Hypovitaminosis D prevalence and determinants among African American and white women of reproductive age: third National Health and Nutrition Examination Survey, 1988-1994. Am J Clin Nutr 76: 187-192. [Crossref]

5. Bläuer M, Rovio PH, Ylikomi T, Heinonen PK (2009) Vitamin D inhibits myometrial and leiomyoma cell proliferation in vitro. Fertil Steril 91: 1919-1925. [Crossref]

6. Halder SK, Sharan C, Al-Hendy A (2012) 1,25-dihydroxyvitamin D3 treatment shrinks uterine leiomyoma tumors in the Eker rat model. Biol Reprod 86: 116. [Crossref]

7. Melamed ML, Michos ED, Post W, Astor B (2008) 25-hydroxyvitamin D levels and the risk of mortality in the general population. Arch Intern Med 168: 1629-1637. [Crossref]

8. Holick MF, Binkley NC, Bischoff-Ferrari HA, Gordon CM, Hanley DA, et al. (2011) Evaluation, treatment, and prevention of vitamin D deficiency: an Endocrine Society clinical practice guideline. J Clin Endocrinol Metab 96: 1911-1930. [Crossref]

9. Ylikomi T, Laaksi I, Lou YR, Martikainen P, Miettinen S, et al. (2002) Antiproliferative action of vitamin D. Vitam Horm 64: 357-406. [Crossref]

10. Forrest KY, Stuhldreher WL (2011) Prevalence and correlates of vitamin D deficiency in US adults. Nutr Res 31: 48-54. [Crossref]

11. Zhao G, Ford ES, Tsai J, Li C, Croft JB (2012) Factors Associated with Vitamin D Deficiency and Inadequacy among Women of Childbearing Age in the United States. ISRN Obstet Gynecol 2012: 691486. [Crossref]

12. Salama SA, Shu-Leong Ho, Hui-Qun W, Tenhunen J, Tilgmann C, et al. (2006) Hormonal regulation of catechol-O-methyl transferase activity in women with uterine leiomyomas. Fertil and Steril 86: 259-262. [Crossref]

13. Sharan C, Halder SK, Thota C, Jaleel T, Nair S, et al. (2011) Vitamin D inhibits proliferation of human uterine leiomyoma cells via catachol-O-methyltransferase. Fertil Steril 95: 247-253. [Crossref]

14. Artaza JN, Norris KC (2009) Vitamin D reduces the expression of collagen and key profibrotic factors by inducing an antifribrotic phenotype in mesenchymal multipoten cells. J Endocrinol 200: 207-221. [Crossref]

15. Halder Sk, Goodwin JS, Al-Hendy A (2011) 1,25-Dihydroxyvitamin D3 reduces TGFbeta-3-induced fibrosis-related gene expression in human uterine leiomyoma cells. $J$ Clin Endocrinol Metab 96: E754-762. [Crossref]

Copyright: $\odot 2018$ Rosen LD. This is an open-access article distributed under the terms of the Creative Commons Attribution License, which permits unrestricted use, distribution, and reproduction in any medium, provided the original author and source are credited. 